\title{
Synthesis, Characterization and Biological Evaluation of Three Derivatives of 2- Hydroxychalcones
}

\section{*AMOLE, LK; BELLO, IA; OYEWALE, AO}

\author{
Department of Chemistry, Faculty of Physical Sciences, Ahmadu Bello University, Zaria, Kaduna State, Nigeria \\ *Corresponding Author Email: azeezamole@yahoo.com
}

\begin{abstract}
In an attempt to compare the efficiency of classical method of synthesizing 2-hydroxychalcones with mechanical and microwave-assisted methods, three derivatives of 2-hydroxychalcone, (E)-3-(4'-methyphenyl)-1-(2hydroxyphenyl)prop-2-en-1-one, (E)-3-(4'-methoxyphenyl)-1-(2-hydroxyphenyl)prop-2-en-1-one and (E)-3-(2'chlorophenyl)-1-(2-hydroxyphenyl)prop-2-en-1-one; were synthesized by a modified Claisen-Schmidt condensation of appropriate acetophenones with various substituted aromatic aldehydes and successfully characterized using spectroscopic analysis. Microwave-assisted and mechanical methods were found to be more efficient in terms of eco-friendly reaction conditions, simple reaction procedure, short reaction time and excellent yields of the product where the reactions took not more than 3 mins to complete under microwave irradiation and not more than 30 mins to complete using mechanical grinding, while it took up to $6 \mathrm{hrs}$ for some reactions to complete under classical method (heating). The synthesized compounds were evaluated for their antimicrobial activity against S. aureus, S. pyogenes, S. feacalis, C. albicans and C. krusei by the agar diffusion method. The compounds exhibited varying degrees of inhibition against the tested pathogens with (E)-3-(2'-chlorophenyl)-1-(2-hydroxyphenyl)prop-2-en-1-one, that has the 2'-chlorophenyl moiety as the B-ring displaying moderate inhibition against the tested pathogens [MIC $=50 \mu \mathrm{g} / \mathrm{ml}]$ with the exception of $S$. feacalis.
\end{abstract}

DOI: https://dx.doi.org/10.4314/jasem.v23i4.12

Copyright: Copyright $\odot 2019$ Amole et al. This is an open access article distributed under the Creative Commons Attribution License (CCL), which permits unrestricted use, distribution, and reproduction in any medium, provided the original work is properly cited.

Dates: Received: 09 November 2018; Revised: 13 March 2019; Accepted 12 April 2019

Keywords: Chalcones, microwave-assisted, grinding and pathogen.

Chalcones have been considered intriguing for the development of pharmaceuticals and a subject of great interest for organic chemists and biochemists all over due to several reasons such as their ease of synthesis and their potential to be used as important intermediates for the synthesis of various heterocyclic compounds (Rathore et al., 2015; Shivshankar et al., 2016). In addition to this, chalcones and several compounds with the chalcone backbone are known for their vast and interesting pharmacological activities and have been reported to possess various biological activities such as antibacterial, antifungal (Bhuiyan et al., 2011; Castelli et al., 2013; Chikhalia et al., 2008), antiviral, anti-inflammatory (Nowakowaska, 2007), antitubercular, analgesic, antimalarial (Lin et al., 2002; Dominguez et al., 2005), antiplatelet, anticancer (Sankappa et al., 2015; Ahmed et al., 2014), antihyperglycemic, anti-ulcerative, antileishmanial, antitumor, antioxidant (Agati et al., 2012; Jin et al., 2013), inhibition of tyrosinate, immunomodulatory, inhibition of leukotriene and inhibition of aldose reductase (Rajat and Abhijit. 2014; Ketabforoosh et al., 2014). The diverse pharmaceutical importance of interest possessed by different chalcone derivatives and the heterocyclic compounds with the chalcone skeleton as reported in the literature inspired us to look for easier, more efficient (shorter time and excellent yield) and eco-friendly method of preparing chalcones that can possibly save time with high yield and, to compare it with conventional methods of synthesis. In this case, microwave-assisted and mechanical (grinding) methods have been considered. Most organic reactions requiring heating have been heated using conventional heat transfer equipment such as heating mantles, water or oil baths. These technique wastes time and more so, the hot surface of the reaction vessel may result in localized heating to produce decomposition products but in the case of microwave irradiation, energy is transferred directly to the reaction mixture, leading to a very rapid temperature increase throughout the sample that may lead to less decomposition products (Santagada, 2009). A diverse range of pharmaceuticals have been synthesized using various merits of microwave technology. For instance, one-pot, coupling reaction for the synthesis of C5alkynyluracil and cytosine glucopyranonucleosides for their cytostatic and antiviral activities, chalcone based 6-carbethoxy-1-one and 2H-indazol-3-ol derivatives for anti-fungal, anti-bacterial and anti-oxidant activities, N-derivative-1,2,3-oxathiazolidine-4-one2,2-dioxides and bioisosteres of trimethadione (TMD, oxazolidine-2,4-dione) for their potential 
anticonvulsant activity, 3-(2-chloro-3[trifluoromethylfuran]phenyl)-1-(5-methyfuran-2-yl) prop-2-en-1-one and 3-(3,4,5-trifluorophenyl)-1-(5methyfuran-2-yl)prop-2-en-1-one for their microbial activities were reported using microwave irradiation and in all cases, high yields were obtained (Kulathooran and Dhamodaran, 2015; Shakil et al., 2013; Dimopoulou et al., 2013; Pastore et al., 2013). This study was designed to compare the efficiency of conventional method of synthesizing 2hydroxychalcone derivatives with solvent-free grinding technique and microwave-assisted method.

\section{MATERIALS AND METHODS}

Synthesis: Three derivatives of 2-hydroxychalcone were synthesised by base-catalysed Claisen-Schmidt condensation of 2-hydroxyacetophenone with 4'methyl-, 4'-methoxyl- and 2'-chloro- benzaldehyde in the presence of $50 \% \mathrm{NaOH}$ and absolute ethanol (Abdullatif et al., 2015). Completion of the reactions was monitored using TLC aluminium sheet pre-coated plate purchased from Merck (silica gel $60 \quad \mathrm{~F}_{254}$, layer thickness $0.2 \mathrm{~mm}$ ). The plate was also used to monitor the separation of compounds and to determine the retardation factor $\left(\mathrm{R}_{\mathrm{f}}\right)$ values. Detection was with $\mathrm{UV}$ light at $254 \mathrm{~nm}$ and $366 \mathrm{~nm}$ (San Gabriel, Model UVGL-58).

Purification of compounds was carried out on a column at atmospheric pressure using silica gel 60 (60120 mesh) purchased from Merck. The columns were packed wet with n-hexane and the compounds were dissolved in dichloromethane and dry-loaded onto the column.

Proton decoupled Bruker $400 \mathrm{MHz}$ spectrometer was used to characterize the prepared compounds. The NMR spectra were recorded with internal standard residual resonance signal of deuterated chloroform and, for some dimethylsulphoxide (DMSO).

The mass spectra were recorded on Agilent technology GC-MS 7890A coupled with MSD 5975C, with GC ALS as injection source. Injection volume $(2 \mu \mathrm{L})$, over maximum temperature of $325^{\circ} \mathrm{C}$ and equilibrium time of $0.25 \mathrm{~min}$. Column size " $30 \mathrm{~m}$ x $320 \mu \mathrm{m}$ x $0.25 \mu \mathrm{m}$ ", initial temperature of $110^{\circ} \mathrm{C}$ and flow rate of 1.6282 $\mathrm{cm}^{3} / \mathrm{min}$. The samples were prepared using methanol as solvent.

The melting point (uncorrected) was determined using Stuart SMP40 automated melting point apparatus (ramp rate $5^{\circ} \mathrm{C}$ per min, start temperature $50^{\circ} \mathrm{C}$ and automatic stop). All the melting temperatures were recorded in ranges.
The IR spectra were recorded on a FTIR-ATR spectrometer (Cary 630), using finely grounded sample.

Synthesis of compounds CKA, CKB and CKC by Conventional method: To a well stirred solution of different benzaldehyde derivatives $(5 \mathrm{mmol})$ each with 2-hydroxyacetophenone $(5 \mathrm{mmol})$ in $98 \%$ ethanol $(20$ $\mathrm{ml}$ ) in a round bottom flask, $50 \% \mathrm{NaOH}$ solution (2 $\mathrm{ml}$ ) was added gradually with constant stirring under reflux for about $5 \mathrm{hrs}$. After completion of the reaction as confirmed by TLC (20\% ethyl acetate in hexane), the reaction mixture (coloured solution) was cool to room temperature, then poured onto crushed ice, acidified with $10 \% \mathrm{HCl}$ until the reaction was slightly acidic to litmus at room temperature and allowed to stand overnight (Abdullatif et al., 2015). The product formed was filtered under suction using a vacuum pump, then washed several times with cold distilled water, dried and recrystallized from $98 \%$ ethanol. The progress of the reaction was monitored by ascending thin layer chromatography hexane:ethyl acetate $(9: 1)$ and the purity of the product was revealed either by reactivity toward iodine vapour or by irradiation with $\mathrm{UV}_{254}$ light (Scheme A).

Synthesis of compounds CKA, CKB and CKC by Mechanical (grinding) method: A mixture of 2hydroxyacetophenone (5 $\mathrm{mmol})$, substituted benzaldehyde $(5 \mathrm{mmol})$ and $\mathrm{NaOH}$ pellets $(15 \mathrm{mmol})$ was ground together in a mortar with a pestle for 10 minutes and left to stand at room temperature for 30 mins. The solid obtained was dissolved in cold distilled water, acidified with $10 \% \mathrm{HCl}$ until the reaction is slightly acidic to litmus at room temperature (Nora and Hussein, 2009). The product formed was filtered under suction using a vacuum pump, then washed several times with cold distilled water, dried and recrystallized from absolute ethanol.

Synthesis of compounds CKA, CKB and CKC by Microwave-assisted method: To a solution of 2hydroxyacetophenone $(5 \mathrm{mmol})$ and substituted benzaldehyde $(5 \mathrm{mmol})$ in $98 \%$ ethanol $(25 \mathrm{ml})$ taken in a round bottom flask, $50 \% \mathrm{NaOH}$ solution $(2 \mathrm{ml})$ was added and the reaction mixture was irradiated using commercial microwave $(900 \mathrm{~W})$ for 180 secs After completion of the reaction as confirmed by TLC (20\% ethyl acetate in hexane), the reaction mixture (coloured solution) was allowed to cool to room temperature, then poured onto crushed ice, acidified with $10 \% \mathrm{HCl}$ until the mixture was slightly acidic to litmus at room temperature and allowed to stand overnight (Pal et al., 2014). The product formed was filtered under suction using a vacuum pump, then 
washed several times with cold distilled water, dried and recrystallized from $98 \%$ ethanol (Scheme A).

Compound CKA: (E)-3-(4'-methyphenyl)-1-(2hydroxyphenyl)prop-2-en-1-one: The title compound (0.79 g [conv]; $0.86 \mathrm{~g}$ [mech]; $0.91 \mathrm{~g}$ [mw], $0.005 \mathrm{~mol})$ was prepared from 2-hydroxyacetophenone $(0.68 \mathrm{~g}$, $0.005 \mathrm{~mol})$ and $p$-tolualdehyde $(0.6 \mathrm{~g}, 0.005 \mathrm{~mol})$ as a yellow crystalline solid, m.pt. 117.7-118.9 ${ }^{\circ} \mathrm{C}$, GCMS $\mathrm{m} / \mathrm{z}=237.2 ; \mathrm{IR}\left(\mathrm{v} \mathrm{cm}^{-1}\right)=1654(\mathrm{C}=\mathrm{O}), 3429(-\mathrm{OH})$, 2996 (Ar C-H), 2914 (Alip C-H), 1580 (Alip C=C). ${ }^{13} \mathrm{C}-\mathrm{NMR}:(100 \mathrm{MHz}, \mathrm{DMSO}) \delta(\mathrm{ppm})=19.57(1 \mathrm{C}$, $\left.\mathrm{CH}_{3}\right), \quad 116.12\left(\mathrm{C}_{3}\right), 117.37\left(\mathrm{C}_{5}\right), 118.44(\alpha-\mathrm{C})$, 118.71( $\left.\mathrm{C}_{1}, \mathrm{Cq}\right), 127.51\left(\mathrm{C}_{2}, \mathrm{C}_{6}\right), 127.92\left(\mathrm{C}_{3}, \mathrm{C}_{5}\right)$, $129.05\left(\mathrm{C}_{6}\right), 130.03\left(\mathrm{C}_{1}, \mathrm{Cq}\right), 134.60\left(\mathrm{C}_{4}\right), 139.50\left(\mathrm{C}_{4}\right.$, $\mathrm{Cq}), 146.68(\beta-\mathrm{C}), 160.66\left(\mathrm{C}_{2}, \mathrm{C}-\mathrm{OH}\right), 191.97(\mathrm{C}=\mathrm{O})$. ${ }^{1} \mathrm{H}-\mathrm{NMR}$ : (400MHz, DMSO, $\left.\mathrm{CDCl}_{3}\right) \delta(\mathrm{ppm})=2.49$ $\left(3 \mathrm{H}, \mathrm{s}, \mathrm{CH}_{3}\right), 12.75(1 \mathrm{H}, \mathrm{s},-\mathrm{OH}), 7.12(2 \mathrm{H}, \mathrm{m}), 7.40$ $(2 \mathrm{H}, \mathrm{m}), 7.67(1 \mathrm{H}, \mathrm{m}), 7.93-8.07(4 \mathrm{H}, \mathrm{m}), 8.36(1 \mathrm{H}$, $\mathrm{m})$.

Compound CKB: (E)-3-(4'-methoxyphenyl)-1-(2hydroxyphenyl)prop-2-en-1-one: The title compound (0.88 g [conv]; $0.95 \mathrm{~g}$ [mech]; 0.98 [mw], $0.005 \mathrm{~mol})$ was prepared from 2-hydroxyacetophenone $(0.68 \mathrm{~g}$, $0.005 \mathrm{~mol})$ and $p$-anisaldehyde $(0.68 \mathrm{~g}, 0.005 \mathrm{~mol})$ as a yellow crystalline solid, m.pt $91.2-92.7{ }^{\circ} \mathrm{C}$. GCMS $\mathrm{m} / \mathrm{z}=254.1 ; \mathrm{IR}\left(\mathrm{v} \mathrm{cm}^{-1}\right)=1640(\mathrm{C}=\mathrm{O}), 3429(-\mathrm{OH})$, 3000 (Ar C-H), 2914 (Alip C-H), 1580 (Alip C=C); ${ }^{13} \mathrm{C}-\mathrm{NMR}:(100 \mathrm{MHz}, \mathrm{DMSO}) \delta(\mathrm{ppm})=53.80(1 \mathrm{C}$, $\left.\mathrm{CH}_{3}\right), 112.83\left(\mathrm{C}_{3}, \mathrm{C}_{5}\right), 116.85\left(\mathrm{C}_{3}\right), 117.01\left(\mathrm{C}_{5}\right)$, $117.40(\alpha-\mathrm{C}), 117.47\left(\mathrm{C}_{1}, \mathrm{Cq}\right), 125.43\left(\mathrm{C}_{1}, \mathrm{Cq}\right)$, $129.08\left(\mathrm{C}_{6}\right), 129.60\left(\mathrm{C}_{2}, \mathrm{C}_{6}\right), 134.62\left(\mathrm{C}_{4}\right), 143.54(\beta-$ $\mathrm{C}), 160.12\left(\mathrm{C}_{4}, \mathrm{C}-\mathrm{OCH}_{3}\right), 160.57\left(\mathrm{C}_{2}, \mathrm{C}-\mathrm{OH}\right), 191.98$ $(\mathrm{C}=\mathrm{O}) ; \quad{ }^{1} \mathrm{H}-\mathrm{NMR}$ : $\left(400 \mathrm{MHz}, \mathrm{DMSO}, \mathrm{CDCl}_{3}\right) \delta$ $(\mathrm{ppm})=2.49\left(3 \mathrm{H}, \mathrm{s}, \mathrm{CH}_{3}\right), 12.75(1 \mathrm{H}, \mathrm{s},-\mathrm{OH}), 6.94-$ $7.01(2 \mathrm{H}, \mathrm{m}), 7.33-7.50(2 \mathrm{H}, \mathrm{m}), 7.64(1 \mathrm{H}, \mathrm{m}), 7.76-$ $7.91(4 \mathrm{H}, \mathrm{m}), 8.28(1 \mathrm{H}, \mathrm{m})$.

Compound CKC: (E)-3-(2'-chlorophenyl)-1-(2hydroxyphenyl) prop-2-en-1-one: The title compound (1.04 g [conv]; $1.13 \mathrm{~g}$ [mech]; $1.17 \mathrm{~g} \mathrm{[mw],} 0.005 \mathrm{~mol})$ was prepared from 2-hydroxyacetophenone $(0.68 \mathrm{~g}$, $0.005 \mathrm{~mol})$ and 2-chlorobenzaldehyde $(0.75 \mathrm{~g}, 0.005$ mol) as a yellow crystalline solid, m.pt $96.3-98.2{ }^{\circ} \mathrm{C}$. GCMS m/z = 258.1; IR $\left(\mathrm{v} \mathrm{cm}^{-1}\right)=1640(\mathrm{C}=\mathrm{O}), 3429$ (-OH), 3000 (Ar C-H), 2914 (Alip C-H), 1580 (Alip $\mathrm{C}=\mathrm{C}) ;{ }^{13} \mathrm{C}-\mathrm{NMR}:\left(100 \mathrm{MHz}, \mathrm{DMSO}, \mathrm{CDCl}_{3}\right) \delta(\mathrm{ppm})$ $=116.55\left(\mathrm{C}_{3}\right), 117.71\left(\mathrm{C}_{5}\right), 118.87\left(\mathrm{C}_{1}, \mathrm{Cq}\right), 122.23(\alpha-$ C), $126.06\left(\mathrm{C}_{5},\right), 127.13\left(\mathrm{C}_{6}\right), 128.66\left(\mathrm{C}_{6}\right), 129.32$ $\left(\mathrm{C}_{4}{ }^{\prime}\right), 130.54\left(\mathrm{C}_{3^{\prime}}\right), 130.89\left(\mathrm{C}_{1}, \mathrm{Cq}\right), 133.62\left(\mathrm{C}_{2}, \mathrm{C}-\right.$ $\mathrm{Cl}), 135.12\left(\mathrm{C}_{4},\right), 138.37(\beta-\mathrm{C}), 161.23\left(\mathrm{C}_{2}, \mathrm{C}-\mathrm{OH}\right)$, $191.93(\mathrm{C}=\mathrm{O})$; ${ }^{1} \mathrm{H}-\mathrm{NMR}$ : (400 MHz, DMSO) $\delta(\mathrm{ppm})$ $=12.75(1 \mathrm{H}, \mathrm{s},-\mathrm{OH}), 6.92-6.95(2 \mathrm{H}, \mathrm{m}), 7.33-7.43$ $(2 \mathrm{H}, \mathrm{m}), 7.45-7.50(2 \mathrm{H}, \mathrm{m}), 7.89-7.95(1 \mathrm{H}, \mathrm{m}), 8.04-$ $8.13(2 \mathrm{H}, \mathrm{m}), 8.17(1 \mathrm{H}, \mathrm{m})$.
Antibacterial evaluation: The antibacterial activities of the compounds were evaluated using the following five pathogenic gram-positive bacteria: Methicillinresistant Staphylococcus aureus (MRSA), Vancomycin-resistant enterococci (VRE), Staphylococcus aureus, Streptococcus pyrogenes and Streptococcus feacalis All were clinical isolates and were obtained from the Department of Medical Microbiology, Ahmadu Bello University Teaching Hospital, Zaria, Nigeria.

Preparation of culture media and compounds: Mueller Hinton agar was used as the growth medium for the microbes. The dehydrated bacteriological culture media was weighed (36 g) and dissolved in distilled water $(100 \mathrm{ml})$ according to the manufacturer's specification. The resultant suspension was dispensed into a clean conical flask and sterilized at $121^{\circ} \mathrm{C}$ for 15 mins in an Adelphi bench autoclave and then poured into previously sterilized petri dishes. The plates were cool and solidify, initial concentration of each of the compounds $(200 \mu \mathrm{g} / \mathrm{ml})$ was prepared by weighing the compound $(0.002 \mathrm{~g})$ and dissolving in DMSO $(10 \mathrm{ml})$ to obtain the stock solution (Lino and Deogracios, 2006)

Antimicrobial profile (zone of inhibition): The antibacterial screening was carried out using the agar diffusion method (Lino and Deogracios, 2006). The prepared medium was seeded with standard inoculums $(0.1 \mathrm{ml})$ of the micro-organism. The inoculums were then spread evenly using a sterilized swab over the surface of the medium. Seeded plates were allowed to dry at $37{ }^{\circ} \mathrm{C}$ for 30 mins inside an incubator. A standard cork borer, $6 \mathrm{~mm}$ in diameter was used to cut a well at the centre of each seeded medium used and $0.1 \mathrm{ml}$ of the solution of the compounds $(200 \mu \mathrm{g} / \mathrm{ml})$ was then introduced into each hole on the surface of the medium. The plates were then incubated at $37{ }^{\circ} \mathrm{C}$ for $24 \mathrm{hrs}$, after which the plates were observed for zone of inhibition of growth. The zones of inhibition were measured with a transparent ruler and the results were recorded in millimetre. Ciprofloxacin $(10 \mu \mathrm{g} / \mathrm{ml})$ was used as the standard drug for comparison.

Determination of minimum inhibitory concentration (MIC): MIC was carried out using broth dilution method (Vollekova et al., 2001; Usman et al., 2007). Mueller Hinton broth was prepared and $10 \mathrm{ml}$ was dispensed into test tubes and sterilized at $121^{\circ} \mathrm{C}$ for 15 mins, the broth was allowed to cool. Mac-Farland's turbidity standard scale number 0.5 was prepared to give a turbid solution. Normal saline was prepared and $10 \mathrm{ml}$ was dispensed into sterilized test tubes and the test micro-organism was inoculated and incubated at 
$37^{\circ} \mathrm{C}$ for $6 \mathrm{hrs}$. After incubation, dilution of the microorganism in normal saline was done until the turbidity matched that of the Mac-Farland scale by visual comparison, at this point the test micro-organisms have a concentration of about $1.5 \times 10^{8} \mathrm{cfu} / \mathrm{ml}$.

Two-fold serial dilution of the compound in the sterilized broth was done to obtain the concentration of $200 \mu \mathrm{g} / \mathrm{ml}, 100 \mu \mathrm{g} / \mathrm{ml}, 50 \mu \mathrm{g} / \mathrm{ml}, 25 \mu \mathrm{g} / \mathrm{ml}$ and 12.5 $\mu \mathrm{g} / \mathrm{ml}$ respectively. The initial concentration was obtained by dissolving $0.002 \mathrm{~g}$ of the compound in 10 $\mathrm{ml}$ of the sterile broth. From the suspension of the micro-organism in normal saline, $0.1 \mathrm{ml}$ was inoculated into the different concentrations of the compound in the Mueller Hinton broth. The broths were then incubated at $37^{\circ} \mathrm{C}$ for $24 \mathrm{hrs}$, after which the test tubes were observed for turbidity (growth). The test tube with lowest concentration of the compound which showed no turbidity was recorded as the minimum inhibitory concentration (MIC).

Determination of minimum bactericidal concentration $(M B C)$ : $\mathrm{MBC}$ was carried out to check whether the test microbes were killed or only their growth were inhibited. Mueller Hinton agar was prepared according to manufacturer's instruction, sterilized at $121{ }^{\circ} \mathrm{C}$ for 15 mins. It was poured into sterilized petri-dishes. The plates were cool and solidify. The content of the MIC test tubes in the serial dilution were sub-cultured on to the prepared plates. The plates were then incubated at $37{ }^{\circ} \mathrm{C}$ for $24 \mathrm{hrs}$, after which the plates were observed for colony growth. The MBC was the plate with lowest concentration of the compound without colony growth (Vollekova et al., 2001; Usman et al., 2007).

\section{RESULTS AND DISCUSSION}

Synthesis of E-1-(2-hydroxylphenyl) prop -2-en-1-one derivatives: In this study, we prepared a series of three derivatives of 2-hydroxychalcones (Figure 1) by refluxing 2-hydroxyacetophenone with various substituted benzaldehyde (Scheme A). The compounds had different shades of yellow (Table 1) and were obtained in good yield (66-81\%). The syntheses were repeated using mechanical method and further repeated under microwave irradiation using a domestic microwave oven. The microwave method was found to be more efficient in terms of eco-friendly reaction conditions, simple reaction procedure, short reaction time and excellent yields of the product compared to the conventional method. For instance, the highest yield for compound CKA was $66 \%$ with the conventional method and the reaction took $6 \mathrm{hrs}$, the same reaction yielded $72 \%$ product by grinding and took about 30 mins to complete while it took just about 3 mins to complete under microwave irradiation with excellent yield of the product $(91 \%)$. To achieve this excellent yield under microwave irradiation using a conventional microwave oven, the irradiation of the reactants was carefully controlled to avoid the drawback that could possible occur using multimode ovens. The reactions were monitored by TLC every 20 secs to avoid over heating of the reaction mixture that could lead to product decomposition. The products obtained after purification were found to be excellent and no undesirable side products were observed as compare to the classical method (Table 2).

The structures were established using IR, NMR and MS analyses. NMR analysis of all the compounds confirmed the formation of the $\alpha-\mathrm{C}$ and $\beta-\mathrm{C}$ of unsaturated carbonyl system (chromophore) and showed that the trans isomer was formed. For instance, carbon resonances ranged from 117 to $122 \mathrm{ppm}$ for $\alpha$ $\mathrm{C}$ and from 138 to $143 \mathrm{ppm}$ for $\beta-\mathrm{C}$ of the conjugated chromophores were observed for $\alpha-\mathrm{C} \delta=116.1-128.1$ ppm; $\beta-\mathrm{C} \delta=136.9-145.4$ (Yazdan et al., 2015).

The delocalization of electrons among the three carbon atoms of the chromophore resulted in the $\beta$-carbon resonance being more deshielded than $\alpha$-carbon. The highly deshielded carbon resonance from 192.43 to 192.97 ppm for carbonyl carbon of the chromophore and from 164 to $166 \mathrm{ppm}$ for hydroxylated carbon of ring A were also observed. The IR spectra confirmed the presence of major functional groups. For instance, the broad intense peaks mostly at $3414 \mathrm{~cm}^{-1}$ for hydrogen bonded hydroxyl groups and the bands ranging from 1636 to $1689 \mathrm{~cm}^{-1}$ for $\mathrm{C}=\mathrm{O}_{\text {str }}$, were observed. The $\mathrm{m} / \mathrm{z}$ values of the compounds equivalent to their respective theoretical molecular weights further confirmed the products.

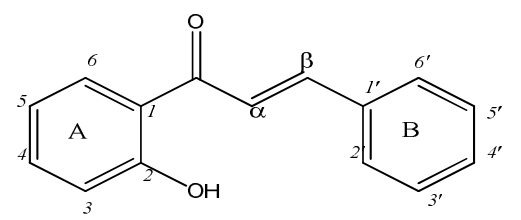

Figure 1: Structure of a 2-hydroxychalcones with position identifiers 
Table 1: Analogues of synthesized derivatives of chalcones with their molecular formulas and colours

\begin{tabular}{|c|c|c|c|c|}
\hline Code & A-ring & B-ring & M.F & Colour \\
\hline CKA & 2-hydroxyphenyl & 4'-methyphenyl & $\mathrm{C}_{16} \mathrm{H}_{14} \mathrm{O}_{2}$ & Yellow \\
\hline CKB & 2-hydroxyphenyl & 4'-methoxyphenyl & $\mathrm{C}_{16} \mathrm{H}_{14} \mathrm{O}_{3}$ & Yellow \\
\hline CKC & 2-hydroxyphenyl & 2'-chlorophenyl & $\mathrm{C}_{15} \mathrm{H}_{11} \mathrm{ClO}_{2}$ & Yellow \\
\hline
\end{tabular}

Table 2: Physical data of synthesized derivatives of chalcones

\begin{tabular}{lllllllll}
\hline Compound & $\begin{array}{c}\text { M.W } \\
(\mathrm{g})\end{array}$ & $\begin{array}{l}\mathrm{m} / \mathrm{z} \\
\text { value }\end{array}$ & $\begin{array}{l}\mathrm{t}_{\mathrm{R}} \\
(\mathrm{s})\end{array}$ & $\begin{array}{l}\mathrm{R}_{\mathrm{f}} \\
(\mathrm{H}: \mathrm{E})\end{array}$ & $\begin{array}{l}\text { M.P range } \\
\left({ }^{\circ} \mathrm{C}\right)\end{array}$ & $\begin{array}{l}\text { Mtd A } \\
\text { Yield }(\%)\end{array}$ & $\begin{array}{l}\text { Mtd B } \\
\text { Yield }(\%)\end{array}$ & $\begin{array}{l}\text { Mtd C } \\
\text { Yield }(\%)\end{array}$ \\
\hline CKA & 238 & 237.2 & 61.90 & 0.58 & $117.1-118.9$ & 66 & 72 & 76 \\
CKB & 254 & 254.1 & 67.14 & 0.60 & $91.2-92.7$ & 69 & 75 & 77 \\
CKC & 258.5 & 258.1 & 58.42 & 0.58 & $96.3-98.2$ & 81 & 88 & 91 \\
\hline
\end{tabular}

$M . W=$ molecular weight (theoretical),$m / z=$ mass spectra value, $t_{R}=$ retention time, $R_{f}=$ retardation factor, $M . P=$ melting point range, $H=$ hexane, $E=$ ethyl acetate $(9: 1), M t d A=$ conventional method, $M t d B=$ grinding method, Mtd $C=$ microwave-assisted method

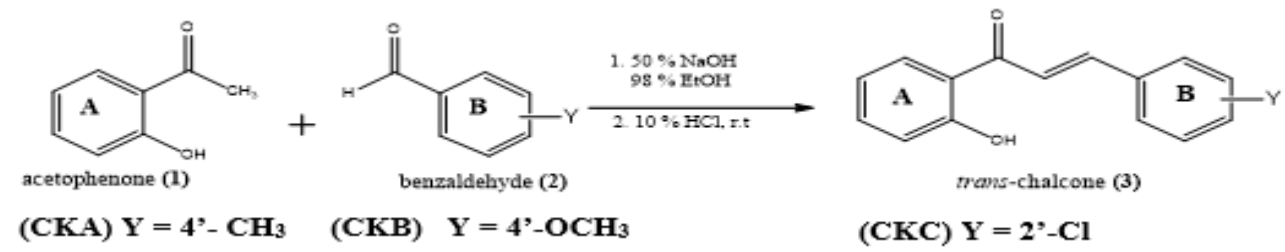

Scheme A: Synthetic pathway for the chalcones

Antibacterial evaluation: The compounds showed varying degrees of antimicrobial activities against the tested three gram-positive bacteria and two candida species based on the observed zones of inhibition which ranged from 19 to $26 \mathrm{~mm}$ [MIC $=50 \mu \mathrm{g} / \mathrm{ml}$; $\mathrm{MBC}=100 \mu \mathrm{g} / \mathrm{ml}$ ] (Table 3). Considering the antibacterial activity, the results demonstrated that the inhibitory effect of the three compounds against $\mathrm{S}$. aureus was independent of the electronic effect of the substituents on the B-ring of the compounds as all three prepared compounds displayed remarkable potency against this pathogen [MIC $=50 \mu \mathrm{g} / \mathrm{ml}$ ]. Compounds CKA and CKB containing electron releasing substituents on the B-ring showed inhibitory effect against $S$. feacalis $[\mathrm{MIC}=50 \mu \mathrm{g} / \mathrm{ml} ; \mathrm{MBC}=100$ $\mu \mathrm{g} / \mathrm{ml}]$ while compound CKC with 2'-chlorophenyl moiety as B-ring, containing electron withdrawing substituent on its B-ring was inactive against this pathogen. It is interesting to note that only the compound $\mathrm{CKC}$ displayed inhibitory effect on the growth of S. pyogenes $[\mathrm{MIC}=50 \mu \mathrm{g} / \mathrm{ml} ; \mathrm{MBC}=100$ $\mu \mathrm{g} / \mathrm{ml}]$. Probable that the activity of the compounds against $S$. pyogenes was influenced by the electronic effect of substituent on the B-ring of the compounds. Considering the antifungal effect, compounds CKB and $\mathrm{CKC}$ exhibited moderate inhibitory effect against C. albicans with MIC value of $50 \mu \mathrm{g} / \mathrm{ml}$, only the compound CKC showed toxicity against C. krusei compound CKA had no effect on the two candida species.

Table 3: Zones of inhibition $(\mathrm{mm})$ prepared derivatives of 2-hydroxychalcone

\begin{tabular}{|c|c|c|c|c|c|}
\hline $\begin{array}{l}\text { Microbes/ } \\
\text { Compounds }\end{array}$ & $\begin{array}{l}\text { S. } \\
\text { aureus }\end{array}$ & $\begin{array}{l}S . \\
\text { pyogenes }\end{array}$ & $\begin{array}{l}\text {. } \\
\text { faecalis }\end{array}$ & $\begin{array}{l}\text { C. } \\
\text { albicans }\end{array}$ & $\begin{array}{l}\text { C. } \\
\text { krusei }\end{array}$ \\
\hline CKA & 21 & 0 & 23 & 0 & 0 \\
\hline CKB & 20 & 0 & 24 & 19 & 0 \\
\hline CKC & 25 & 23 & 0 & 26 & 28 \\
\hline CIP & 28 & 29 & 27 & NT & NT \\
\hline FLU & NT & NT & NT & 30 & 31 \\
\hline
\end{tabular}

Table 4: MIC \& MFC $(\mu \mathrm{g} / \mathrm{ml})$ regimes of prepared derivatives of 2-hydroxychalcone

\begin{tabular}{|c|c|c|c|c|c|c|}
\hline $\begin{array}{l}\text { Microbes/ } \\
\text { Compounds }\end{array}$ & & $\begin{array}{l}S . \\
\text { aureus }\end{array}$ & $\begin{array}{l}S . \\
\text { pyogenes }\end{array}$ & $\begin{array}{l}\text { S. } \\
\text { feacalis }\end{array}$ & $\begin{array}{l}\text { C. } \\
\text { albicans }\end{array}$ & $\begin{array}{l}\text { C. } \\
\text { krusei }\end{array}$ \\
\hline CKA & MIC & 50 & - & 50 & - & - \\
\hline $\mathrm{X}=\mathrm{H}, \mathrm{Y}=4^{\prime}-\mathrm{CH}_{3}$ & $\mathrm{MBC}$ & 100 & - & 100 & - & - \\
\hline CKB & MIC & 50 & - & 50 & 50 & - \\
\hline $\mathrm{X}=\mathrm{H}, \mathrm{Y}=4^{\prime}-\mathrm{OCH}_{3}$ & $\mathrm{MBC}$ & 200 & - & 100 & 200 & - \\
\hline CKC & MIC & 25 & 50 & - & 50 & 50 \\
\hline $\mathrm{X}=\mathrm{H}, \mathrm{Y}=2^{\prime}-\mathrm{Cl}$ & $\mathrm{MBC}$ & 50 & 100 & - & 100 & 100 \\
\hline
\end{tabular}

AMOLE, LK; BELLO, IA; OYEWALE, AO 
Conclusion: The present study compares the efficiency of conventional method of synthesizing 2hydroxychalcone derivatives with solvent-free grinding technique and microwave-assisted methods. The effectiveness of syntheses under solvent- free grinding technique and microwave irradiation was established with the elimination of harmful solvents, ease of work-up, shorter reaction time, mild reaction conditions, eco-friendly reaction condition and excellent yields of the products as compared to conventional method. The study established the antimicrobial potential of the prepared derivatives of 2-hydroxychalcone.

Acknowledgments: The authors are thankful to Prof. John Igoli of Federal University of Makurdi, Nigeria and Mr Bashir of Multi-User Laboratory, Ahmadu Bello University, Nigeria for spectroscopic analyses

\section{REFERENCES}

Abdellatif, KRA; Elshemy, HAH; Salama, SA; Omar, HA (2015). Synthesis, antioxidant, antiinflammatory and analgestic agents. J. Enzyme Inhib. Med. Chem. 30(3): 484-491.

Agati, G; Azzarello, E; Pollastri, S; Tattini, M (2012). "Flavonoids as antioxidants in plants: location and functional significance, Plant Sci. 196: 67-76.

Ahmed, N; Konduru, NK; Ahmad, S; Owais, M (2014). Synthesis of flavonoids based novel tetrahydropyran conjugates (Prins products) and their antiproliferative activity against human cancer cell lines. Eur. J. Med. Chem. 75: 233-246.

Bhuiyan, MMH; Hossain, MI; Mohammad Al-Amin, MM (2011). Microwave-assisted efficient synthesis of chalcones as probes for antimicrobial activities. J. Chem. 1(1): 21-28.

Castelli, V; Zacchino, SA; Lo, SN; Ribas, JC; Lobo, G; Charris-charris, J; Enriz, RD (2013). In vitro antifungal evaluation and structure-activity Relationships of a new series of chalcone derivatives and synthetic analogues, with inhibitory properties against polymers of the fungal cell wall, ARKIVOC 9: 1999-2013.

Chikhalia, KH; Patel, MJ; Vashi, DB (2008). Design , synthesis and evaluation of novel quinolyl chalcones as antibacterial agents. ARKIVOC 8: 189-197.

Dominguez, JN; Leon, C; Rodrigues, J; Dominguez, NG; Gut, J (2005). Synthesis and evaluation of new antimalarial phenylurenyl chalcone derivatives. J. Med. Chem. 48(10): 3654-3658.

Dimopoulou, A; Manta, S; Kirtsis, C; Gkaragkouni, DN; Papasotirious, I; Balzarini, J; Komiotis, D (2013). Rapid microwave enhanced synthesis of C5-alkynyl pyranonucleosides as nivel cytotoxic antitumor agents. Bioorg. Med. Chem. Lett. 23: 1330-1333.

Jin, C; Liang, YJ; He, H; Fu, L (2013). Synthesis and antitumor activity of novel chalcone derivatives. Biomed. Pharmacother 67: 215-217.

Ketabforoosh, SHME; Kheirollahi, A; Safavi, M Esmati, N (2014). Full paper synthesis and anticancer activity evaluation of new dimethoxylated chalcone and flavanone analogs. Arch. Pharm. Chem. Life Sci. 347: 1-8.

Kulathooran, S; Dhamodaran, M (2015). Synthesis and biological evaluation of some new chalcones using anhydrous potassium carbonate as an efficient basic catalyst by conventional and microwave-assisted technique, IJPSR 6(7): 30273033.

Lin, Y; Zhou, Y; Flavin, MT; Zhou, L; Nie, W; Chen, F (2002). Chalcones and flavonoids as antituberculosis agents. Bioorg. Med. Chem. 10: 2795-2802.

Lino, A; Deogracios, O (2006). The in-vitro antibacterial activity of Annona senegalensis, Securidacca longipendiculata and Steanotaenia araliacea. Afr. J. Health Sci. 1(6): 31-35.

Nora, MR; Hussein, FZ (2009). Atom-efficient, solvent-free, green synthesis of chalcones by grinding. Syn. Comm. 39: 2789-2794.

Nowakowaska, Z (2007). A review of anti-infective and anti-inflammatory chalcones. Eur. J. Med. Chem. 42: 125-137.

Pal, R; Sarkari, T; Sarkari, T (2014). Improved microwave-induced synthesis of indolylchalcones. Arch. Appl. Sci. Res. 6(3): 138141.

Pastore, V; Sabatier, L; Enrique, A; Marder, M; Bruno-Blanch, LE (2013). Synthesis and anticonvulsant activity of bioisosteres of trimethadione, N-derivatives-1,2,3-oxathiazole4-one-2,2-dioxides from $\alpha$-hydroxyamides. Bioorg. Med. Chem. Lett. 21: 841-846. 
Rajat, G; Abhijit, D (2014). Synthesis and biological activities of chalcones and their heterocyclic derivatives: A review. WJPPS. 3(3): 578-595.

Rathore, MM; Rajput, PR; Parhate, VV (2015). Synthesis and antimicrobial activity of some chalcones and flavones. Int. J. Chem. Phy. Sci. 4: 473-477.

Sankappa, RU; Isloor, AM; Pai, KSR; Fun, HK (2015). Synthesis and in vitro biological evaluation of new pyrazole chalcones and heterocyclic diamides as potential anticancer agents. Arab. J. Chem. 8: 317-321.

Santagada, V; Frecentese, F; Perissutti, E; Fiorino, F; Severino, B; Caliendo, G (2009). Microwaveassisted technology in drug discovery. Mini Rev Med Chem. 3: 340-58.

Shakil, NA; Singh, MK; Sathiyendiran, M; Kumar, J; Padaria, JC (2013). Microwave synthesis, characterization and bioefficacy evaluation of novel chalcone based 6-carbethoxy-2cyclohexen-1-one and 2H-indazole-3-ol derivatives. Eur. J. Med. Chem. 59: 120-131.
Shivshankar, S; Chavan, S; Vibhute, Y (2016). Solvent-free synthesis of chalcones and antioxidant activity. J. Adv. Chem. Sci. 2(4): 373375.

Usama, H; Abdulrahman, FT; Ladan, AA (2007) Phytochemical and evaluation of tribulus terrestris L (Zygophyllaceae) growing in Nigeria. Res. J. Biol. Sci. 2(3): 244-247.

Vollekova, A; Kostalova, S; Sochorova, R (2001) Isoquinoline Alkaloids from Mahonia aquifolium stem bark is active against Malassezia Sp. Folia. Microb. 46: 107-111.

Yazdan, KS; Sagar, GV; Shaik, BA (2015). Biological and synthetic potentiality of Chalcones: A review. J. Chem. Pharm. Res.7 (11): 829-842. 